\title{
Is all publicity good publicity? Ask Peloton
}

\author{
Rodney Andrew Carveth \\ Morgan State University \\ School of Global Journalism and Communication \\ Baltimore, MD 21251
}

\begin{abstract}
Controversial ad campaigns from companies such as Nike have suggested that "any publicity is good publicity." This case study of a controversial 2019 advertising campaign by Peloton, where one its ad not only was critically panned, but resulted in Peloton losing nearly $\$ 1$ billion in market value. The case shows that not only was Peloton tone deaf about the message the company is putting out there, it defended itself by insulting its consumer base.
\end{abstract}

Keywords - apologies, controversial advertising, image restoration

SUGGESTED CITATION: Carveth, R. A. (2020). Is All Publicity Good Publicity? Ask Peloton. Proceedings of the International Crisis and Risk Communication Conference, Volume 3 (pp. 49-52). Orlando FL: Nicholson School of Communication and Media. https://www.doi.org/10.30658/icrcc.2020.12

\section{INTRODUCTION}

One common joke that we have seen in television sitcoms and advertising over the years are those clueless husbands who give vacuum cleaners to their wives as birthday and holiday gifts. The husband then wonders why his wife is angry and giving him the cold shoulder. It doesn't dawn on him that nothing says romance like giving your wife tools for housework.

It appears that the advertising team for stationary bike manufacturer, Peloton, missed this long history of gifts you shouldn't give when they created and released an ad featuring a rail-thin woman receiving a Peloton stationary bike from her husband for Christmas. The wife is shown first as being surprised by the gift. The ad then proceeds to portray scenes of how the woman gets up in the early morning hours, next to her sleeping husband, to work out on her Peloton, and how she is on the bike day in and day out. The ad ends a year later with the wife showing her husband how grateful she is by showing a compilation of her posts of her daily workouts, in order that her husband knows that she is not slacking off. Peloton released the ad a week before Thanksgiving as part of a winter holiday ad campaign.

To Peloton's surprise, the ad generated a considerable amount of backlash. Within the first week, the ad been viewed two million times on the brand's YouTube channel, but thumbs down ratings outnumbered thumbs up ratings five to one. Critics attacked the expense of the product itself - it retails for $\$ 2,245$, more than double $(\$ 1048)$ what the average family pays for the Christmas holidays on gifts and food [1] (Tompor, S., 2019, Dec. 5).

Controversial ad campaigns from companies such as Nike have suggested that "any publicity is good publicity." Using Situation Crisis Communication Theory, this case study examines when that saying is true, and when a brand is being tone deaf about the message the company is putting out there.

\section{LITERAURE REVIEW}

A number of advertisers have not shied away from controversy. Nike's advertising campaign to celebrate the $30^{\text {th }}$ anniversary of the slogan "Just Do It" featured former San Francisco 49ers quarterback, Colin Kaepernick, who was blackballed from playing in the National Football League for kneeling in protest during the playing of the National Anthem. Bennetton has a history of featuring ads that took on controversial issues, such as gay rights and the death penalty. Budweiser and Airbnb have addressed the immigration issue in their ad campaigns, while Ben and Jerry's has tackled climate change. While the campaigns have generated a lot of media attention, and calls for boycotts, the brands have not only survived the firestorm, but thrived.

Peloton's experience was different. Among the reactions, a tweet from @ClueHeywood was typical: “... the newest commercial about the vlogging $116 \mathrm{lb}$ woman's YEARLONG fitness journey to becoming a 112 lb woman who says "I 
didn't realize how much this would change me" is just ri-god-damn-diculous. Come on." Other comments fell along the same lines:

"It's clear this woman doesn't need a Peloton. She needs a good therapist and a divorce lawyer."

"Absolutely $100 \%$ chance that the husband in the Peloton ad is abusive."

"The only way to enjoy that Peloton ad is to think of it as the first minute of an episode of Black Mirror."

"I really thought Christmas music before Christmas was the worst, then I saw a Peloton ad."

The media reaction was not much different, as seen from the headlines:

Forbes: Is Peloton's New Ad Sexist?

Ad Age: Peloton Ad Controversy Has Experts in Debate over Long-term Effects for the Brand

Variety: Social-Media's Latest Exercise: Getting Worked Up Over a Peloton Ad

Business Insider: An over-the-top Peloton ad showing the super-wealthy biking in penthouses, zen gardens, and sunrooms led to one of the year's best Twitter threads

Vox: Peloton's terrifying new ad is the best horror movie in recent memory

Not all the media reports were that harsh, but, took some effort to defend Peloton. Here is a sampling of the headlines:

PR Week: Maybe the mom in Peloton's ad actually wanted the stationary bike?

Boston Magazine: Don't be Mad at the Peloton Ad. Be Mad at the Industry That Encouraged It

The Federalist: In Defense of That Peloton Bike Ad: Nothing's Wrong with High-End Fitness

Worse than the criticism, however, the backlash resulted in a major hit to Pelton stock. On Monday, December 2, Peloton opened at 35.30 and closed at 36.84. After barely two days of social media backlash, the company's stock fell more than $9 \%$ on Dec. 3 (ending at 33.48), causing it to lose $\$ 942$ million of its market value in a single day. The drop brought Peloton's market cap to roughly \$9.4 billion. In the coming weeks, Peloton did not match its December 2 high trading at 24.98 when the Trump Administration announced its nationwide lockdown because of the coronavirus.

The social media backlash toward the ad was one reason investors lost faith in the company. The reaction by the company itself contributed to its economic circumstances.

\section{IMAGE RESTORATION DISCOURSE STRATEGIES}

As noted by Carveth, Ferraris \& Backus [2], reputation hinges upon the judgments that key publics make based upon an organization's -- or an individual's -- behavior. Sound reputations protect the organization or individual against existing and potential problems such as those that arise when controversial incidents occur [3]. A previously solid reputation will not only help an organization or individual to ride out the storm, but also to successfully recover in the wake of its damage.

Image restoration becomes an issue when organizations or individuals have passed the point of anticipation and have lost the opportunity to act proactively in protecting themselves. All efforts thereafter must be made with the goal of regaining the confidence of all relevant publics, minimizing negative publicity, and returning the organization to either its previous state or one better.

Analysis of crisis communication often focuses on the content of external communications such as apologies and speeches of self-defense [4]. Benoit's theory of image restoration comprises the typologies of self-defense to create a detailed typology of image restoration strategies for organizations [5].

Benoit [6] has identified two simple components of an attack:

1. The accused is held responsible for an action.

2. That act is considered offensive.

In addition, public figures and organizations need to address a variety of stakeholder groups, each with their own set of goals and concerns. Benoit [6] urges that in crisis situations, it is important to prioritize these groups and tailor messages to their specific concerns.

The theoretical foundation of Image restoration theory is that communication is a goal-directed activity and maintaining a positive reputation is one of the central goals of communication. Because for both individuals and organizations maintaining a favorable image is of great importance, when events occur that threaten that image (especially when the threat has come from an action by the individual or organization), it is important to have strategies to restore that image. Benoit's Image Restoration Theory focuses on the variety of message options at a crisis communicator's disposal. The theory comprises five broad categories of image repair strategies and three of these are divided into more specific subcategories of tactics.

Denial is the first category of repair strategies. There are four variants within this category: simple denial, shifting the blame, separation, and denying that the act was harmful [7]. Simple denial is a rejection of the charges. The accused party 
may deny that the act occurred or that they even performed the act. For example, at first, Enron denied that it had engaged in any financial wrongdoing [8]. Shifting of blame entails an argument that another party is actually responsible for the undesirable act. Blaney, Benoit, and Brazeal [9] demonstrated that both Ford and Bridgestone tried to focus the blame on the other company in the wake of the incidents involving rollovers of Ford sports utility vehicles that used Firestone tires. In an analysis of Texaco's racism scandal, in which executives were taped using racial slurs against African-Americans, Brinson and Benoit [7] also identified a previously unrecognized form of shifting of blame that they termed separation. Separation seeks to place the blame on a small portion of an organization that can be separated from the remaining and presumably good part. Finally, denying that the act was harmful is an admission by the accused that they committed the perceived wrong, however, they refute the fact that anyone was damaged by it [7].

Evasion of responsibility is the second category. Here the offender attempts to dodge or reduce responsibility of wrongdoing. Simply put, evasion of responsibility involves the crafting of excuses [7]. This general strategy has four different versions: provocation, defeasibility, accident, and good intentions. Provocation occurs when the accused party claims that the offensive act was merely a response to another's offensive act, and that the behavior should be viewed as a reasonable reaction to that provocation. Another form of evading responsibility is defeasibility. Here, the accused party alleges a lack of information about or control over key elements of the situation. Arthur Andersen tried to blame the Enron scandal not on their accounting practices, but on the downturn in the economy [8]. Similarly, President George W. Bush attempted to use defeasibility in defending his first term as president during an appearance on "Meet the Press" [10]. Answering criticism that the U.S. couldn't find the weapons of mass destruction that provided the primary rationale to attack Iraq, Bush argued that f Hussein secretly destroyed, moved, or hid the weapons, then Bush cannot be held responsible for not finding them.

A third option to use in evading responsibility is to claim that the offensive action was accidental. If the audience can be convinced that the negative action was a mishap, then the reasoning is that the accused will be held less accountable and the damage to image will be mitigated. Part of the image repair strategy used by the U.S. Navy in 2001 when the USS Greenville collided with a Japanese trawler, killing nine people, was that the incident was an accident [11]. A final strategy within this category entails an attempt to convince the audience that the offensive act was performed with good intentions, that although an undesirable situation occurred, the accused meant well [6].

The third major category involves reducing the offensiveness of events. This category is made up of six subcategories: bolstering, minimization, differentiation, transcendence, attack accuser, and compensation. Bolstering attempts to boost audience good will toward the accused in order to offset the negative feelings connected with the offense. Stressing the good traits of the offender or describing the offender's positive acts in the past achieves it. In the wake of the Enron crisis, the American Institute of Certified Public Accountants (AICPA) engaged in bolstering by stressing the positive activities and attributes of the profession [12]. Minimization seeks to reduce the negative feelings associated with the wrongful act so that it appears less harmful than it may have initially seemed to be [6]. A third option is the employment of differentiation, distinguishing the present negative act from other similar, but more offensive actions in the hopes that this will reduce negative sentiment toward the act and concurrently toward the accused [7]. U.S. Congressman Gary Condit attempted to employ differentiation in explaining his role in the disappearance of Chandra Levy, an intern in his office with whom he was having an affair [13]. Transcendence attempts to place the act within a broader, more favorable context and appeals to values and group loyalties in order to improve the offender's image. In attempting to shore up his sagging approval ratings, in an April 2004 press conference, President George W. Bush employed transcendence as a strategy by claiming he was a "war president" and thus should not be judged according to the usual criteria for evaluating presidential performance [10]. When attacking the accuser, the offender tries to cast doubt upon the attacker's credibility to reduce the intensity of the attack. The sixth and final strategy within reducing offensiveness is compensation. In this strategy, the accused offers to reimburse the victim of the offense, which, if it is acceptable to the victim, should help reduce the negative feelings arising from a failure of some sort [7].

The fourth category of image restoration theory is corrective action. Strategies of corrective action involve the offender promising to correct the problem. The offender may promise to restore the situation to the state of affairs before the event by repairing existing damages, and/or promising to take preventive action (such as revising policies) to avoid a recurrence [6].

The last category of defensive rhetoric is mortification. Apologists who use mortification confess to the wrongdoing and ask for forgiveness or express regret [5]. The rationale here is that the admission of guilt and a display of regret can often lead the audience to pardon the negative action [7].

Benoit [5] argues that the more successful apologies will be those that use a combination of strategies. He also counsels the apologist to admit fault (if at fault) immediately and to report plans to correct problems and prevent recurrences. He argues that denial, shifting blame, and minimization do not typically work to preserve an apologist's image. Thus, Benoit argues that corrective action and mortification are more effective strategies than denial, shifting blame, and minimization.

Peloton's reaction was not helpful: "We constantly hear from our members how their lives have been meaningfully and positively impacted after purchasing or being gifted a Peloton Bike or Tread, often in ways that surprise them. While we are disappointed in how some have misinterpreted this commercial, we are encouraged by - and grateful for - the outpouring of support we've received from those who understand what we were trying to communicate." (Italics mine). 
In other words, Peloton responds here by shifting the blame -- if it wasn't for consumers who were too stupid to figure out the ad's message, there wouldn't be any problem.

What Peloton's reaction fails to take into account is that the message of the ad IS confusing. When you purchase a Peloton bike, you are not buying just a product/service but also what the lifestyle represents. The theme is aspirational. That is, by buying Peloton, you are improving your life by getting fit. Yet, in the ad, the woman is attractive and slim when she gets the present, and the same a year later. How do you see any aspirational achievement? Is the goal to take a year of selfies for her husband?

So, Peloton commits two major mistakes here. It confuses that audience with its ad, and then blames the audience for not getting the message. Peloton failed here where other controversial advertising campaigns succeeded because they did not insult their market.

\section{CONCLUSION}

So, not all publicity is good publicity. Some publicity can be bad, even economically damaging. Consumers don't like to be insulted.

Fortunately, consumers don't have long memories. Beginning with the nationwide shutdown in March, Peloton's revenue grew $66 \%$ as more people both purchased its fitness equipment and subscribed to its live classes. During the shutdown, subscribers doubled to 886,100 , as its stock price climbed from $\$ 25$ per share in March to $\$ 40$ on May 6 , 2020. The company projected heightened demand for its bikes well into the summer of 2020 [14].

\section{AUTHOR BIOGRAPHY}

Rod Carveth (Ph.D., University of Massachusetts) is Associate Professor of Strategic Communication at the School of Global Journalism and Communication at Morgan State University in Baltimore, MD (rodcarveth@gmail.com)

\section{REFERENCES}

[1] Tompor, S. (2019, Dec. 5). Peloton's controversial bike ad stirred immediate reaction when I watched it. Detroit Free Press. Available at: https://www.freep.com/story/money/personal-finance/susan-tompor/2019/12/05/peloton-bike-ad-commericalcontroversy-complaints/2606718001

[2] Carveth, R., Ferraris, C., \& Backus, N. (2006). "Fighting the journalistic perfect storm: the duke administration's handling of the lacrosse team sex scandal.". Proceedings of the Association for Business Communication.

Available at: http://www.businesscommunication.org/conventions/Proceedings/2006/ABC2006Proceedings.html

[3] Baker, G. F. (2001). Race and reputation: Restoring image beyond the crisis. In R. L. Heath, \& G. Vasquez (Eds.), Handbook of Public Relations (pp. 513-520). Thousand Oaks, CA: Sage Publications, Inc.

[4] Seeger, M. W., Sellnow, T., \& Ulmer, R. R. 2003. Communication and organizational crisis, Westport, CT: Praeger.

[5] Benoit, W. L. (1995). Accounts, excuses, and apologies: A theory of image restoration strategies. Albany, NY: State University of New York Press.

[6] Benoit, W. L. (1997). Image repair discourse and crisis communication. Public Relations Review, 23, $177-186$. https://doi.org/10.1016/S0363-8111(97)90023-0

[7] Brinson, S. L., \& Benoit, W. L. (1999). The tarnished star: Restoring Texaco's damaged public image. Management Communication Quarterly, 12, 483-510. https://doi.org/10.1177/0893318999124001

[8] George, A. M., \& Evuleocha, S, (2003). Denials, Excuses, Justifications, and Apologies: Restoring tarnished reputations after the year of corporate malfeasance. what worked and what didn't. Proceedings of the 2003 Association for Business Communication Annual Convention. http://www.businesscommunication.org/conventions/Proceedings/2003/PDF/04ABC03.pdf

Available at:

[9] Blaney, J. R., Benoit, W. L., \& Brazeal, L. M. (2002). Blowout! Firestone's image restoration campaign. Public Relations Research, 28, 379-392. https://doi.org/10.1016/S0363-8111(02)00163-7

[10] Benoit, W. L. (2006). President Bush's image repair effort on Meet the Press: The complexities of defeasibility. Journal of Applied Communication Research, 34, 285-306. https://doi.org/10.1080/00909880600771635

[11] Drumheller, K., \& Benoit, W. (2004). USS Greeneville collides with Japan's Ehime Maru: Cultural issues in image repair discourse. Public Relations Review, 30, 177-185. https://doi.org/10.1016/j.pubrev.2004.02.004

[12] Rogers, R., Dillard, J., \& Yuthas, K. (2005). The accounting profession: Substantive change and/or image management. Journal of Business Ethics, 58, 159-176. https://doi.org/10.1007/s10551-005-1401-z

[13] Len-Rios. M., \& Benoit, W. (2004). Gary Condit's image repair strategies: determined denial and differentiation. Public Relations Review, 30, 95-106. https://doi.org/10.1016/j.pubrev.2003.11.009

[14] Hanbury, M. (2020, May 7). Peloton reports 66\% increase in sales as coronavirus keeps consumers working out at home. Business Insider. Available at: https://www.businessinsider.com/peloton-sales-surge-coronavirus-keeps-consumersworking-out-at-home-2020-5 